\title{
Vseživljenjsko izobraževanje in osnovna šola
}

Martin Kramar

\author{
Učenje je bolj ali manj trajna človekova aktivnost, s katero človek spreminja \\ svoje ravnanje. Iz tega se vidi, da je učenje že samo po sebi človekova vseživljenjska \\ aktivnost.
}

Pri tem mislim na najpreprostejše učenje, $s$ katerim človek na podlagi izkušnje spremeni svoje ravnanje. Danes pa je učenje pogosto mišljeno kot človekova posebna namerna aktivnost, usmerjena v pridobivanje novega znanja, $v$ razvoj sposobnosti, spretnosti in načinov ravnanja. To je predvsem šolsko (ali temu podobno) organizirano učenje. V sodobnem času se zavedamo pomena znanja, človekovih sposobnosti in njegove osebnostne razvitosti, zato poudarjamo nujnost nenehnega učenja. Mislim pa, da je bolj kot nenehno učenje mišljeno nenehno izobraževanje (education permanente), ki naj bi postalo človekova vseživljenjska dejavnost. Glede na to bi bilo namesto vseživljenjskega učenje ustreznejše govoriti o vseživljenjskem izobraževanju, kajti učenje je že samo po sebi človekova vseživljenjska dejavnost, izobraževanje pa ne. Z izobraževanjem mislim na namerno, sistematično, organizirano, načrtno pridobivanje znanja, razvijanje sposobnosti in usposabljanje za racionalno rabo znanja, spretnosti in sposobnosti. (Prodanović, 1974, str. 18) S tem pa izobraževanja ne omejujem le na inštitucionalizirano šolsko pojavnost, temveč ga pojmujem kot vseživljenjski proces, ki se kaže v različnih vidikih, poteka različno in v različnih oblikah. Gre torej za to, da učenje kot imanentna človekova aktivnost, ki jo mnogi ljudje uresničujejo le na ravni najpreprostejših izkušenj, ne ostane zgolj na tej ravni, temveč postane človekova potreba in stalna zavestna namerna dejavnost. S tem pa se učenje razširi in ni le sestavina človekove vsakdanje aktivnosti, temveč postaja tudi zavestna in namerna dejavnost usmerjena $\mathrm{k}$ določenim ciljem.

\section{Vseživljenjskso izobraževanje se prične v osmovni šoli}

Zanimivo in značilno je, da se vseživljenjsko izobraževanje najpogosteje omenja v zvezi z izobraževanjem odraslih. To daje zmoten vtis, da se vseživljenjsko izobraževanje prične šele v dobi človekove odraslosti. Takšno gledanje je vsekakor zmotno in ima za razvoj vseživljenjskega izobraževanja lahko neugodne posledice. Zato želim v tem prispevku poudariti nujnost in pomen kontinuitete izobraževanja skozi ves formalni izobraževalni sistem in vsa človekova življenjska obdobja. Poleg kontinuitete je pomembna tudi integracija človekovega vseživljenjskega izobraževanja, ki ima različne namene in poteka na različnih področjih.

V pričujočem prispevku gledam na vseživljenjsko izobraževanje $z$ vidika osnovnega izobraževanja oziroma $z$ vidika osnovne šole. Izhajam iz podmene, da se vseživljenjsko izobraževanje prične $\mathrm{z}$ osnovnim izobraževanjem. Pomembne osnove za to pa človek razvija že v predšolskem obdobju. Iz tega se vidi tudi potreba po usmerjenosti osnovnega šolanja $\mathrm{v}$ razvoj vseživljenjskega izo- braževanja. Takšna usmerjenost bi morala biti jasno nakazana v ciljih osnovnošolskega izobraževanja, posledično pa v vseh sestavinah in $\mathrm{v}$ izvajanju vzgojno-izobraževalnega procesa $\mathrm{v}$ osnovni šoli.

\begin{tabular}{|c|c|c|c|}
\hline \multirow[b]{2}{*}{$\begin{array}{l}\text { predšolsko } \\
\text { obdobje }\end{array}$} & \multicolumn{3}{|c|}{ vseživljenjsko izobraževanje } \\
\hline & $\begin{array}{l}\text { osnovno } \\
\text { solanje }\end{array}$ & $\begin{array}{l}\text { nadalinje } \\
\text { šlanje }\end{array}$ & $\begin{array}{l}\text { izobraževanje } \\
\text { odraslih }\end{array}$ \\
\hline
\end{tabular}

Skica prikazuje časovno zaporedje, gledano z vidika sistema vzgoje in izobraževanja. V okviru izobraževanja odraslih, gledano vsebinsko, pa lahko poteka tudi osnovno ali drugo izobraževanje, ki ga večina ljudi opravi v obdobju pred odraslostjo.

\section{Vseživljenjsko izobraževanje in cillii osnovne šole}

V ciljih osnovnošolskega izobraževanja, ki jih navaja Zakon o osnovni šoli (Šolska zakonodaja, 1996), usmerjenosti osnovne šole $\mathrm{v}$ razvijanje ali spodbujanje vseživljenjskega izobraževanja ne najdemo. Še več, med cilji osnovnošolskega izobraževanja sintagme vseživljenjsko izobraževanje sploh ni. Ta cilj se le implicitno kaže v tem, da je med cilji osnovnošolskega izobraževanja tudi »...pridobivanje znanj za nadaljnje šolanje« (Šolska zakonodaja, 1996, str. 109). Toda nadaljnjega šolanja ne moremo enostavno enačiti z vseživljenjskim izobraževanjem. Poleg tega pa tudi med cilji nadaljnjega šolanja (Zakon o gimnazijah in $\mathrm{Za}$ kon o poklicnem in strokovnem izobraževanju) o vseživljenjskem izobraževanju ne najdemo ničesar. To, da je »spodbujanje vseživljenjskega izobraževanja« med cilji sistema vzgoje in izobraževanja v Republiki Sloveniji, ki jih navaja Zakon o organizaciji in financiranju vzgoje in izobraževanja, ni dovolj. Omenjeni cilj, to je »razvoj in spodbujanje vseživljenjskega izobraževanja«, bi moral biti med cilji osnovnošolskega in nadaljnjega splošnega, poklicnega in strokovnega izobraževanja na vseh stopnjah šolanja zelo jasno zapisan. Smiselno pa bi bilo, če bi ga našli tudi pri izobraževanju odraslih, pri katerem se vseživljenjskost izobraževanja pojavlja kot načelo.

Čeprav gre le za pravne dokumente, ki urejajo sistem vzgoje in izobraževanja, se moramo zavedati, da cilji, zapisani v njih, nakazujejo usmerjenost delovanja vzgojno-izobraževalnih inštitucij in razvojne cilje celotnega sistema vzgoje in izobraževanja. Po tem pa se praviloma ravna tudi vzgojno-izobraževalni proces, ki ga šole uresničujejo na posameznih stopnjah šolanja. Zato ni vseeno, ali je tako pomemben cilj, kot je razvijanje vseživljenj- 
skega izobraževanja, med cilji šole na posamezni stopnji šolanja ali ga ni.

Potrebna je kontinuiteta tega cilja, od začetnega šolanja dalje, saj je vseživljenjsko izobraževanje pomemben človekov in družbeni eksistenčni pogoj, vse bolj pa postaja tudi zelo pomembna konceptualna značilnost in globalni cilj celotne vzgojno-izobraževalne dejavnosti.

\section{Vseživljenjsko izobraževanje in vsebina vzgojno=izobraževalnega procesa v osnovmi รัฮाi}

Usmerjenost osnovne šole v razvoj in spodbujanje človekovega vseživljenjskega izobraževanja bi se dalje moralo izražati tudi $\mathrm{v}$ vsebini vzgojno-izobraževalnega procesa, predvsem $\mathrm{v}$ njenem didaktično kategorialnem položaju. Vsebina je nosilna komponenta vzgojno-izobraževalnega procesa, materialna osnova in konkretizacija ciljev ter objekt didaktične komunikacije in interakcije med subjekti procesa. $Z$ vidika vseživljenjskega izobraževanja mora biti vsebina informativno odprta, komunikativna, medpredmetno korelirana in integrirana. Vsebina naj ne bo zaprta količina šolskega znanja, ki ima podlago v katalogih znanja in je usmerjeno $\mathrm{k}$ pridobivanju ocen, temveč naj bo funkcionalna celota, ki vsebuje temeljno principialno znanje, hkrati pa nakazuje nova vprašanja, probleme in usmerja $\mathrm{k}$ nadaljnjemu izobraževanju.

\section{Vseživljenjsko izobraževanje in položaj učencev v vzgojno-izobraževalnem procesu}

Za razvoj človekovega vseživljenjskega izobraževanja je zelo pomemben položaj učencev v vzgojno-izobraževalnem procesu. Ta naj bo takšen, da bodo učenci že v osnovni šoli spoznavali in usvajali pravilne metodološke pristope, razvijali lastne metode dela, s katerimi bodo sami uspešno iskali, odkrivali, oblikovali in usvajali znanje in s tem tudi razvijali sposobnosti. Pri tem ne gre samo za aktivnost, ki je pogoj uspešnosti učencev, temveč za razvoj aktivnosti kot sestavine vzgojno-izobraževalnih ciljev. Učenci naj bodo aktivni $v$ vseh fazah izobraževalno-vzgojnega procesa, kajti le tako bodo spoznali aktivnost celovitega spoznavnega oziroma vzgojno-izobraževalnega procesa. Skupaj z učitelji so soustvarjalci vzgojno-izobraževalnega procesa. Čeprav so učenci subjekti, ki se učijo in razvijajo, učitelji pa subjekti, ki posredujejo znanje, usmerjajo aktivnost učencev, spremljajo, preverjajo, korigirajo in dopolnjujejo, vrednotijo in ocenjujejo njihove (učenčeve) dosežke, naj bo med njimi intelektualno didaktična komunikacija in interakcija. Pouk naj bo v vseh svojih fazah odprt in naj učencem omogoča ter spodbuja svobodno razmišljanje. Med učitelji in učenci naj bodo takšni odnosi, da bodo učenci hoteli in si upali izražati svoje misli in tudi drugačne poglede. Ob tem pa naj učenci spoznavajo tudi merilo za presojo pravilnosti dosežkov, se navajajo na utemeljevanje spoznanj, lastnih misli in pogledov. Za učenčevo samostojno učenje in nadaljnje (vseživljenjsko) izobraževanje je zelo pomembno, da znajo učenci načrtovati, organizirati in sami voditi svoje učenje in izobraževanje, ki ju spoznavajo in se $\mathrm{z}$ aktivno vlogo $\mathrm{v}$ vseh fazah vzgojno-izobraževalnega procesa zanju tudi usposabljajo že v osnovni šoli.

V vzgojno-izobraževalnem procesu v osnovni šoli naj učenci spoznajo različne vire in prenosnike informacij in se jih naučijo uporabljati. Ob tem se uvajajo v šolske knjižnično-informacijske sisteme in po njih v informacijske sisteme zunaj šole. Tako se učenci že v osnovni šoli srečujejo tudi z multimedijskim didaktičnim sistemom vzgojno-izobraževalnega procesa, ki je v vseživljenjskem izobraževanju, zlasti pri izobraževanju odraslih, zelo pomemben.

$\mathrm{Z}$ razvijanjem ustreznega pedagoško-didaktičnega položaja in aktivne vloge učencev v vzgojno-izobraževalnem procesu šola neprisiljeno razvija tudi njihove interese in jih motivira za pridobivanje in usvajanje znanja. Z ustrezno spodbujevalno storilnostno usmerjenostjo k pridobivanju in usvajanju znanja, razvijanju sposobnosti in osebnostnih lastnosti bo šola vplivala tudi na razvoj potreb učencev po nadaljnjem izobraževanju. Odkloni storilnostne usmerjenosti šole $\mathrm{k}$ šolskim ocenam, testnim rezultatom in tekmovalnim dosežkom pa bodo (dolgoročno) interes in potrebe učencev po stalnem izobraževanju zmanjševali. Tudi zaradi razvijanja in spodbujanja vseživljenjskega izobraževanja moramo biti zato do takšnih odklonov zelo pozorni in kritični.

\section{Skllepne misli}

Vseživljenjsko izobraževanje postaja vse pomembnejša človekova in družbena potreba. Njenemu zadovoljevanju bodo posamezniki in družba namenjali vse več pozornosti, osebne energije, časa in finančnih sredstev. Človekovo znanje, njegove sposobnosti in osebnostne lastnosti, človekova sposobnost in pripravljenost za delovanje na podlagi znanja in sposobnosti postajata bistven eksistenčni pogoj sodobnega človeka in družbe. Zato postaja izobraževanje zelo pomembna človekova vseživljenjska dejavnost, ki se prične že v osnovnošolskem izobraževanju in ne šele v obdobju po končanem formalnem izobraževanju. Osnovna šola je časovno precej oddaljena od izobraževanja odraslih, ki vseživljenjsko izobraževanje zelo aktualizira in poudarja, vendar človek že v osnovnošolskem izobraževanju sistematično razvija in oblikuje temelje svojega vseživljenjskega izobraževanja. Zato je treba tudi to stopnjo šolanja upoštevati kot zelo pomemben integralni del človekovega vseživljenjskega izobraževanja.

\section{dr. Martin Kramar}

izredni profesor na Pedagoški fakulteti v Mariboru

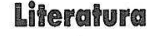

Glasser, W. 1994: Kvalitetna škola. Zagreb: Educa

Hameyer, U., Lauterbach, R., Wichmann, J. 1992: Innovationsprozesse in der Grundschule. Bad Heilbrunn/Obb: Julius Klikhardt.

Krajnc, A. 1995: Futurološki pogled na šolo in permanentno izobraževanje. Ljubljana: Sodobna pedagogika, št. 5-6, 9-10.

Matijević, M. (urednik) 1991: Osnovna škola na pragu XXI. stoljeća. Zagreb: Filozofski fakultet Sveučilišta u Zagrebu.

Pivac, J. 1995: Škola u svijetu promjena. Zagreb: Institut za pedagogijska istraživanja Filozofskog fakulteta Sveučilišta u Zagrebu.

Prodanović, T., Ničković, R. 1974: Didaktika. Beograd: Zavod za udžbenike i nastavna sredstva.

Šolská zakonodaja I. 1996. Ljubljana: Ministrstvo za šolstvo in šport. 